\title{
Reproductive biology of the deep-sea pennatulacean Anthoptilum murrayi (Cnidaria, Octocorallia)
}

\author{
D. O. Pires*, C. B. Castro, J. C. Silva \\ Museu Nacional/Universidade Federal do Rio de Janeiro, Quinta da Boa Vista, s/n, São Cristóvão, \\ Rio de Janeiro 20940-040, Brazil
}

\begin{abstract}
Anthoptilum murrayi has been reported from the North Atlantic, northern Mid-Atlantic Ridge, Indian Ocean and in waters around New Zealand and Australia. Recently, this species was also recorded in deep waters off Brazil, southwestern Atlantic. It was from this region $\left(13^{\circ}\right.$ to $\left.22^{\circ} \mathrm{S}\right)$ that specimens were collected, in 1300 to $1799 \mathrm{~m}$, to determine the reproductive biology of $A$. murrayi using histological methods. The colony polyparium was divided into 3 zones (distal, medial and basal) to evaluate differences in gamete development between zones; dissected polyps were examined from the 3 zones to estimate fecundity. The species appears to display a continuous and long breeding activity rather than any seasonal reproductive pattern. Most oocytes were in the earliest stages of development and basal polyps presented the highest frequency of small eggs. The large mature oocytes (up to $1200 \mu \mathrm{m}$ ) indicate that $A$. murrayi produces lecithotrophic larvae. Females had 0 to 90 oocytes per polyp and 25713 to 35918 oocytes per colony. Male colonies of similar size to the female samples were shown to have 6 to 76 cysts per polyp and 14014 to 27019 cysts per colony. A. murrayi is a sessile gonochoric species with a 1:1 sex ratio and is most likely a broadcast spawner. The species has high fecundity, large eggs that could represent larger targets for sperm, primitive spermatophores, as well as a large number of polyps per colony. These factors, along with a patchy distribution, would enhance the chance of fertilization for A. murrayi and may guarantee a successful reproductive strategy for this species.
\end{abstract}

KEY WORDS: Pennatulacea $\cdot$ Gametogenesis $\cdot$ Fecundity $\cdot$ Deep-sea

\section{INTRODUCTION}

Knowledge of the reproductive biology of organisms is essential to understanding how populations can be maintained and renewed. Data comprising, for example, the sexuality, reproductive mode, sex ratio and seasonality of reproduction of species of concern are crucial to the establishment of better policies for the management, conservation and recovery strategies of degraded areas.

Reproduction and propagation of shallow-water tropical corals have been extensively studied, particularly for the scleractinians (Harrison \& Wallace 1990). The reproductive biology of octocorals has also focused primarily on tropical species (Simpson 2009), and there is currently an initiative towards reviewing the literature on this subject (Kahng et al. 2008). How- ever, data from a larger number of octocoral species is required for any robust analysis of reproductive biology for this group.

Information on reproductive traits of deep-sea corals is more recent and limited. Some deep-sea studies impose serious restrictions on specimen data acquisition and many studies use material already available in collections and are thus not ideally preserved. As such, there are often few temporal series making it difficult to present conclusive investigations on timing of the gametogenic cycle, duration of gametogenesis, seasonality and specific dates for gamete release or planulation. In spite of these logistical restraints, partially accumulated data can show general trends of deep-sea coral reproduction, and these are fundamental to maximizing outcomes and economizing effort when planning new sampling initiatives. 
For general reproductive patterns in deep-sea corals, data exist primarily for groups such as scleractinians (see review in Waller 2005), stylasterids (Brooke \& Stone 2007) and octocorals (review in Simpson 2009).

In terms of the sexual status and mode of development, most shallow-water scleractinians are hermaphroditic and spawn gametes for external fertilization (Harrison \& Wallace 1990). In contrast, the limited available data on the deep-sea scleractinians to date shows that most are gonochoric broadcast spawners. The exceptions are the species that have polyps adapted for brooding, such as the Antarctic cup corals, Flabellum spp. (Waller et al. 2008) and 3 species of Caryophyllia which are hermaphroditic (Waller 2005, Waller et al. 2005).

Twelve deep-sea stylasterids, belonging to the genera Stylaster, Errinopora, Distichopora, Cyclohelia and Criptelia were studied by Brooke \& Stone (2007). All were gonochoric brooders, in contrast to the shallowwater Stylaster roseus, which may be hermaphroditic (Brooke \& Stone 2007).

Despite the ecological importance of cold-water octocorals, there are few published studies on their reproductive processes (Cordes et al. 2001, Orejas et al. 2002, 2007), although some studies have included various aspects on the reproduction of pennatulaceans (Chia \& Crawford 1973, Eckelbarger et al. 1998, Tremblay et al. 2004, Soong 2005, Edwards \& Moore 2008, 2009). However, only 2 studies have focused on deep-water sea pens (Kophobelemnon stelliferum, Rice et al. 1992, and Umbellula lindahli, Tyler et al. 1995).

Gonochorism is the dominant pattern found for octocorals, with only a few alcyonacean taxa being hermaphroditic, e.g. Sinularia exilis (Benayahu 1997) and some species of Heteroxenia and Xenia (Benayahu 1991, 1997). The frequency of brooding versus broadcast spawning in octocorals varies with taxonomic order (Simpson 2009). All pennatulaceans studied to date are broadcast spawners.

Anthozoans, especially scleractinians and octocorals, are the most dominant macrobenthic group in some deep-sea areas off Brazil (Castro et al. 2006). The pennatulaceans are common octocorals, living in sediment areas surrounding deep-sea coral habitats. The order Pennatulacea occurs in all oceans, and species are generally adapted to living on soft sediments (Williams 1995). Pennatulids are characterized by an oozooid (the persistent and modified primary polyp), a proximal muscular peduncle and a distal polyp-bearing rachis (polyparium) with autozooids (polyps with 8 well-developed tentacles and mesenteries) and siphonozooids (polyps a with strongly developed siphonoglyph and reduced or absent tentacles) (Bayer et al. 1983).

The group has approximately 200 species (Williams, 1995). Castro \& Medeiros (2001) and Castro et al. (2006) recorded 13 species of pennatulaceans, belong- ing to 6 families, along the Brazilian coast. Seven of these recorded species came from depths below $200 \mathrm{~m}$. The sea pen Anthoptilum murrayi Kölliker 1880 has been reported from the shelf to the upper continental slope of the North Atlantic, the northern Mid-Atlantic Ridge, Faraday Seamount, the Indian Ocean and waters around New Zealand and Australia (Jungersen 1904, Thomson \& Henderson 1906, Deichmann 1936, Cryer et al. 2002, McFadden et al. 2006, Molodtsova et al. 2008, Mortensen et al. 2008, Cairns et al. 2009). The first specimens from the South Atlantic were collected off Brazil, from $13^{\circ}$ to $22^{\circ} \mathrm{S}$ (Pinto 2008). Most often, several specimens were sampled in a single dredge (up to 52 colonies per dredge), which suggests high local densities.

The present study describes the main characteristics on the reproductive biology of a member of the family Anthoptilidae, which has been considered one of the most primitive of the pennatulaceans (Doulan 2008). The gametogenesis in male and female colonies of Anthoptilum murrayi is described and estimates of their high fecundity are presented. Results of their reproductive characteristics are compared with data available from other corals, particularly for sea pens. As noted by Edwards \& Moore (2009), A. murrayi confirmed the pattern of both gonochorism and broadcast spawning, which may be conserved at the order level in Pennatulaceans.

\section{MATERIALS AND METHODS}

Colonies were collected off Bahia and Espírito Santo States between $13^{\circ}$ and $21^{\circ} \mathrm{S}$ in 2000 during the Living Resources in the Exclusive Economic Zone (REVIZEE) Score Central Project (see Lavrado \& Ignácio 2006), and in 2003 off Rio de Janeiro State (Campos Basin, 21 ${ }^{\circ}$ to $22^{\circ} \mathrm{S}$ ) during the Campos Basin Deep-Sea Environmental Project/PETROBRAS (Ocean Prof I and II campaigns) (see Falcão et al. 2006). Specimens were up to $75 \mathrm{~cm}$ in height (Fig. 1) and were collected at depths between 1051 and $1799 \mathrm{~m}$ using otter trawls. A relatively large number of specimens were collected during sampling, but only a few of these colonies $(\mathrm{n}=24)$ were undamaged and still bore intact polyps suitable for study. The 24 colonies were collected in February (4 specimens), June (9), July (4) and August (7).

Gametogenesis was examined using histological methods. All colonies were fixed and preserved in $70 \%$ alcohol, as they had been primarily collected for taxonomic studies. The use of alcohol-preserved specimens for histology was far from ideal and posed many limitations during the various histological procedures. Tissues were fragile from alcohol preservation and the process of extending the sections prior to application to 


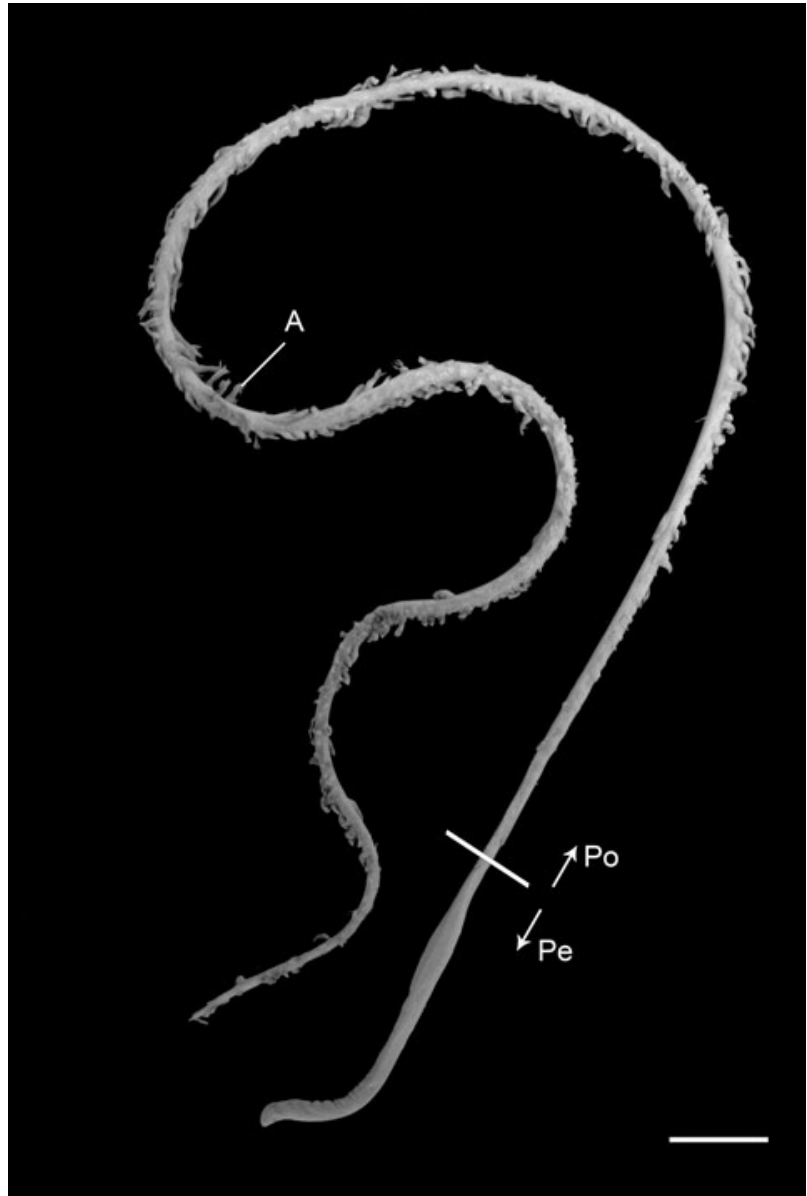

Fig. 1. Anthoptilum murrayi. A deep-sea pennatulacean specimen collected off Brazil, southwestern Atlantic (Museu Nacional, Rio de Janeiro, MNRJ 4281). Po: polyparium; Pe: peduncle; A: autozooid. Scale bar $=2 \mathrm{~cm}$

the slides was difficult, with several sections lost during reagent transfer. Polyps were dissected dehydrated by graded alcohol series and embedded in paraffin wax using standard methodology (Pantin 1948). It was ascertained that thinner sections were more adequate to obtain better histological results and as such sections of 4 to $6 \mu \mathrm{m}$ were stained using Mallory's triple stain for histological observations. Gametogenesis was classified according to histological characteristics and sizes of both the oocytes and spermatic cysts. Stages of development are arbitrary as they reflect a continuous process (Wourms 1987). Gamete development classification followed Pires et al. (1999), where Stage I represented the beginning of development, Stage II an intermediate step (vitellogenic process in oogenesis) and Stage III mature oocytes and/or spermatic cysts. Measurements of the different developmental stages of oocytes and spermatic cysts were made using an eyepiece micrometer in an Olympus
BH2 microscope. The longest axis of the oocytes and spermatic cysts were measured. Only perfect oocytes with nuclei were measured, to avoid remeasurement of the same cells.

The polyparium of male and female colonies (from June 2000) was divided into 3 zones (distal, medial and basal) to evaluate differences in gamete development between zones. Polyps from each zone were examined using histology to access the synchrony of developmental stages among different colony zones. Polyps from different zones were also examined through dissections to determine polyp fecundity (= number of oocytes or spermatic cysts per polyp). The same colonies were used in both cases.

Gametes of 4 polyps from each zone, as well as the total number of polyps in each colony, were counted in 4 male and 4 female colonies, all collected in June 2000 (total = 48 male and 48 female polyps). One of the male colonies was used solely for fecundity counts. Counts were made using a Zeiss SV6 stereomicroscope and all oocytes and spermatic cysts seen at 25 to $32 \times$ magnification were counted. Colony fecundity was estimated as the average number of gametes in polyps from different zones of colonies multiplied by the average number of polyps of a given colony. Colony lengths were also measured.

Sex ratio was tested using a chi-square comparing the observed and expected frequencies in a 1:1 ratio (null hypothesis). Such an expected ratio was designated as the sum of males (M) and females (F) observed divided by 2 ( $n$ each sex $=M / 2+F / 2$ ).

Differences in fecundity were tested using nested ANOVA, with polyp position nested in colony. Prior to testing, homocedasticity of variance (Levene's test) and normality (Kolmogorov-Smirnov test) were tested. No significant departures from ANOVA premises were found, except for number of cysts $\left(F_{11,36}=2.59, \mathrm{p}=\right.$ 0.016). Significant differences $(p<0.05)$ were further examined with post hoc tests (Tukey's HSD). All tests were performed using Statistica 6.0 (StatSoft).

\section{RESULTS}

All examined colonies (females: 28 to $58 \mathrm{~cm}$; males: 24 to $64 \mathrm{~cm}$ long) presented gametes and were gonochoric. It was not possible to distinguish the sex of the fixed colonies without histological preparations. Sex ratio did not significantly differ from 1:1 (11 males and 13 females examined through histology, $\chi^{2}=0.167, \mathrm{df}=1, \mathrm{p}=0.683$ ).

Gametes appeared only in the autozooids. Mature sexual cells were visible with the naked eye (Fig. 2). A layer of mesoglea surrounded the sexual cells and stained an intense blue. The mesoglea thickened in the oocytes as they developed. 


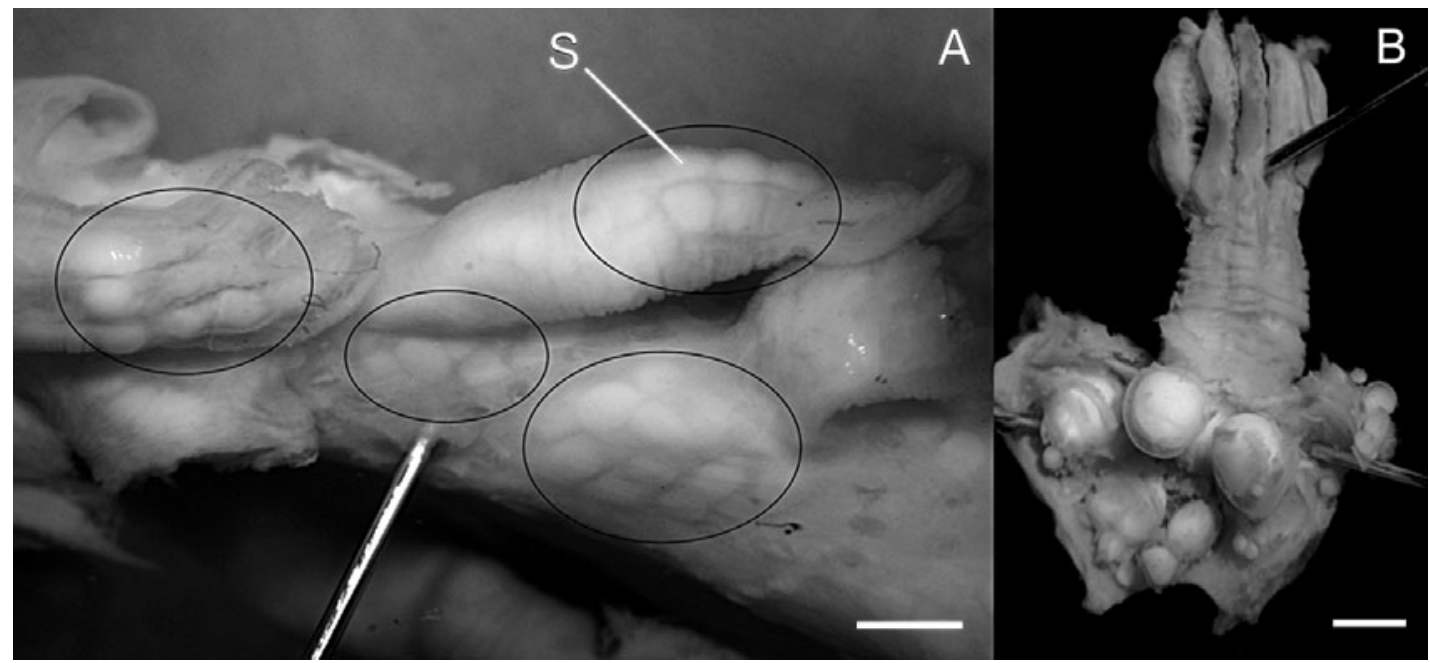

Fig. 2. Anthoptilum murrayi. (A) Mature sperm cysts in a male colony. S: spermatic cysts. (B) Dissected polyp of a female colony showing oocytes in different stages of development. Scale bars $=1 \mathrm{~mm}$

Oogenesis was classified into 3 stages (Fig. 3A-C). Stage I represented primary development, Stage II an intermediate step (most of the vitellogenesis phase) and Stage III characterized mature sexual cells. Early Stage I cells stained bluish purple. Pre-vitellogenic Stage I cells usually presented a more homogenous cytoplasm, and some cells stained light rose. The nucleus was most often positioned centrally. The smallest Stage I cell observed was $10 \mu \mathrm{m}$ (longest axis) and the largest was $350 \mu \mathrm{m}$, with a mean $( \pm \mathrm{SD})$ value of $115.32 \pm 53.21 \mu \mathrm{m}$. Stage II oocytes stained dark rose. More lipid vesicles were present and had begun to coalesce. Stage II oocytes showed a migration of the nucleus to the cell border and they ranged in size from approximately 220 to $540 \mu \mathrm{m}$, with a mean value of $368.28 \pm 83.89 \mu \mathrm{m}$. Stage III oocytes stained from dark rose to red. The cytoplasm became full of distinct colorless lipid vesicles and the nucleus had moved to the periphery of the cell. Stage III oocytes ranged in size from approximately 490 to $1200 \mu \mathrm{m}$, with a mean value of $901.07 \pm 180.07 \mu \mathrm{m}$.

Spermatogenesis was also divided in 3 development stages (Fig. 3D-F). Stage I spermatic cysts ranged from 30 to $300 \mu \mathrm{m}$, with a mean value of $94.67 \pm 54.17 \mu \mathrm{m}$. In Stage II, cysts had a lumen present and occasionally some tails of spermatozoa could be seen. Stage II cysts ranged from 50 to $650 \mu \mathrm{m}$, with a mean value of $299.03 \pm 126.15 \mu \mathrm{m}$. In Stage III cysts, the heads of spermatozoa were located near the periphery of the cyst and their tails projected into the center. Stage III cysts ranged from 240 to $740 \mu \mathrm{m}$, with a mean value of $383.33 \pm 85.67 \mu \mathrm{m}$.

Male and female cells were associated with the follicle layers (differentiated and flattened gastrodermal cells) during all stages of gametogenesis. These follicle layers were inconspicuous in some cells, but usually their thickness increased as the growth of sexual cells advanced. Follicle layers were approximately $20 \mu \mathrm{m}$ thick in sperm cysts and $70 \mu \mathrm{m}$ thick around Stage III oocytes (Fig. 3C).

Anthoptilum murrayi is more likely to present continuous breeding activity than seasonal cycles, since gametes in different stages of development were observed from single seasons (Fig. 3B). The lack of continuous sampling meant that an estimate of the duration of the reproductive cycle could not be obtained.

Polyps from different areas of the colony were shown to bear gametes. In females, most of the oocytes were in the earliest stages of development and polyps from the basal area presented the highest frequency of very small cells (Fig. 4).

High frequencies of small oocytes (up to $200 \mu \mathrm{m}$ ) and low frequencies of large oocytes were observed for all sampling periods (Fig. 5). All spermatic cysts observed in specimens collected in August were larger than $200 \mu \mathrm{m}$. Samples from August also showed the highest frequencies of the largest size classes of cysts and the occurrence of the largest cysts observed for all samples (between 700 and $740 \mu \mathrm{m}$ ) (Fig. 5).

There were large numbers of gametes in both male and female colonies. Examined specimens from June 2000 had 414 to 645 polyps in female colonies (up to $747 \mathrm{~mm}$ in length) and 429 to 655 polyps in male colonies (up to $650 \mathrm{~mm}$ in length). Female colonies presented 0 to $90(47.6 \pm 12.4)$ oocytes per polyp and an estimated 25713 to 35918 (31 $465 \pm 5080$ ) oocytes per colony. Oocytes per polyp differed from polyp to polyp (ANOVA, $F=3.69, \mathrm{df}=8, \mathrm{p}=0.003$ ). Tukey's HSD showed these differences always occurred between the basal polyps and the middle or distal polyps (8 out 

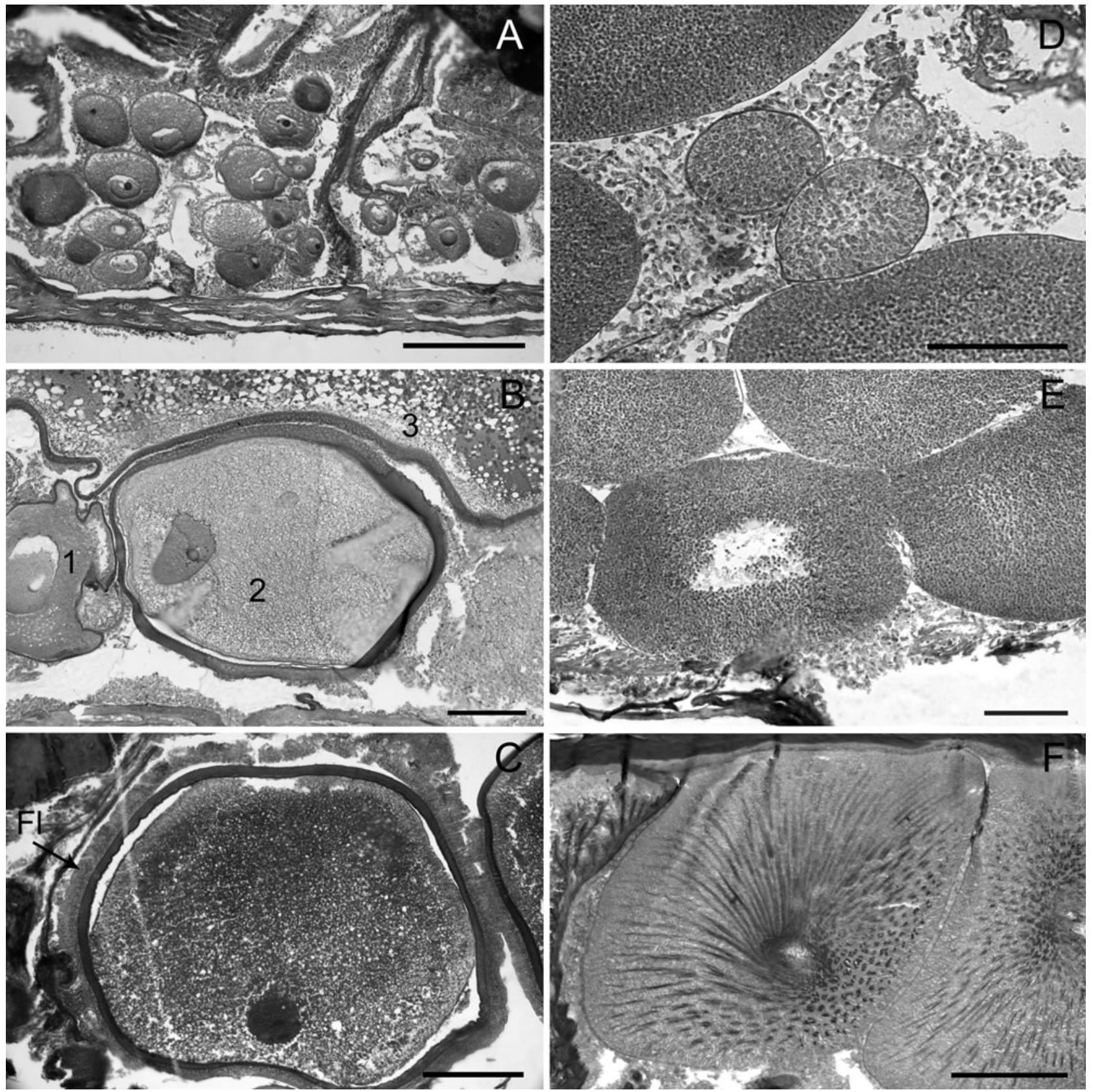

Fig. 3. Anthoptilum murrayi. Histology of the different stages of gametogenesis. (A) Stage I oocytes, (B) Stage II oocyte (2), but also showing a Stage I oocyte (1) and part of a Stage III oocyte (3), (C) Stage III oocyte, (D) Stage I sperm cyst, (E) Stage II sperm cyst and (F) Stage III sperm cyst. Fl: follicle cell layer. Scale bars $=(A, C) 200 \mu \mathrm{m}$ and (B, D-F) $100 \mu \mathrm{m}$

of 32 such pairs). The number of oocytes per colony also differed significantly from colony to colony $(F=7.33, \mathrm{df}=3, \mathrm{p}<0.0006)$. Male colonies of similar sizes presented 6 to $76(36.6 \pm 3.6)$ cysts per polyp and an estimated 14014 to 27019 (19871 \pm 5793) cysts per colony. The number of cysts differed significantly among the different polyp positions on the colony $(F=9.00, \mathrm{df}=8, \mathrm{p}=0.000001)$, but did not differ significantly among colonies $(F=1.17, \mathrm{df}=3, \mathrm{p}=0.33)$. Basal polyps presented significantly less cysts than middle and distal polyps (Tukey's HSD, 19 out of 32 such comparisons).

Anthoptilum murrayi is most likely a broadcast spawner, as no embryonic or planula stages were seen in the gastrovascular cavities of the polyps. In addition, large mature oocytes and intact cysts were commonly seen above the pharynx, well up in the hollow tentacles. Fig. 6 shows a longitudinal section of a male polyp 

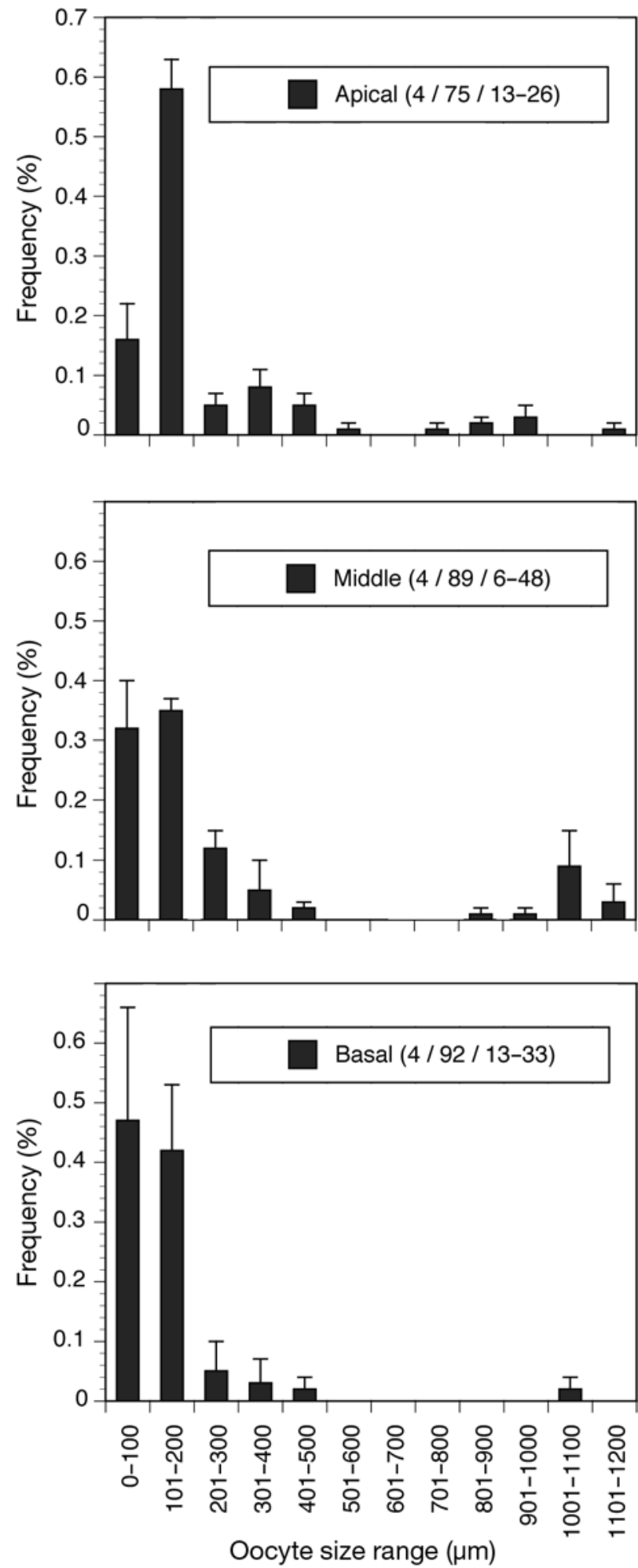

Fig. 4. Anthoptilum murrayi. Relative frequency of oocyte size classes in polyps from the apical, medial and basal zones of colonies. All colonies collected in June 2000. Key notation: colony zone (no. colonies/total no. gametes examined/minimum-maximum no. gametes examined in a single colony). Error bars are $+\mathrm{SE}$ where mature cysts are seen in the tentacles and at the base of the polyp. It seems that intact cysts passed by the side of the pharynx and reached the tentacles.

\section{DISCUSSION}

Although the lack of a continuous sampling design imposed limitations on the present study, the available samples were sufficient to detect main features of reproductive biology for this species. Anthoptilum murrayi followed the same general pattern of gonochoric sexual development as seen in other pennatulaceans and some octocorals (Table 1). The few available data show that sea pens have a sex ratio of $1: 1$ (Edwards \& Moore 2008, 2009), and this was observed in A. murrayi.

The largest size of oocytes of Anthoptilum murrayi (1200 $\mu \mathrm{m})$ was approximately $60 \%$ larger than the largest pennatulacean eggs recorded to date. The maximum oocyte size recorded for both Kophobelemnon stelliferum and Umbellula lindahli is $800 \mu \mathrm{m}$ (Rice et al. 1992, Tyler et al. 1995), and Pennatula aculeata had a maximum oocyte size of $880 \mu \mathrm{m}$ (Eckelbarger et al. 1998). Very large oocytes (up to $1200 \mu \mathrm{m}$ ) have also been recorded in other cold-water octocorals such as Dasystenella acanthina (Orejas et al. 2007), as well as in solitary deep-sea scleractinians belonging to the genus Flabellum (Waller et al. 2008). Increased oocyte size is correlated with some corals with an extended oogenic cycles, but not all corals with long cycles produce large oocytes (Harrison \& Wallace 1990). This size of oocyte also indicates that $A$. murrayi produces lecithotrophic larvae. In octocorals, larger oocytes are often associated with species which have these nonfeeding larvae (Edwards \& Moore 2009) and most planula observed appear to be lecithotrophic (Simpson 2009). Lecithotrophy is the pattern seen among pennatulaceans (Eckelbarger et al. 1998) and is also observed in deep-sea broadcast spawning scleractinians (Waller 2005).

Environmental factors influence coral sexual processes, synchronizing the reproductive cycles (affected by temperature, day length and salinity) and the timing of spawning within a species, which is affected by tidal patterns and lunar rhythms (Harrison \& Wallace 1990). However, the great majority of deep-sea species reproduce aperiodically or continuously, not requiring periodic environmental cues to regulate their gametogenic cycles (Young 2003). Anthoptilum murrayi differs from most pennatulaceans, presenting a possible continuous and long breeding activity rather than seasonal cycles. Continuous or quasi-continuous reproductive cycles are not the general pattern in pennatulaceans, but they have also been observed in 

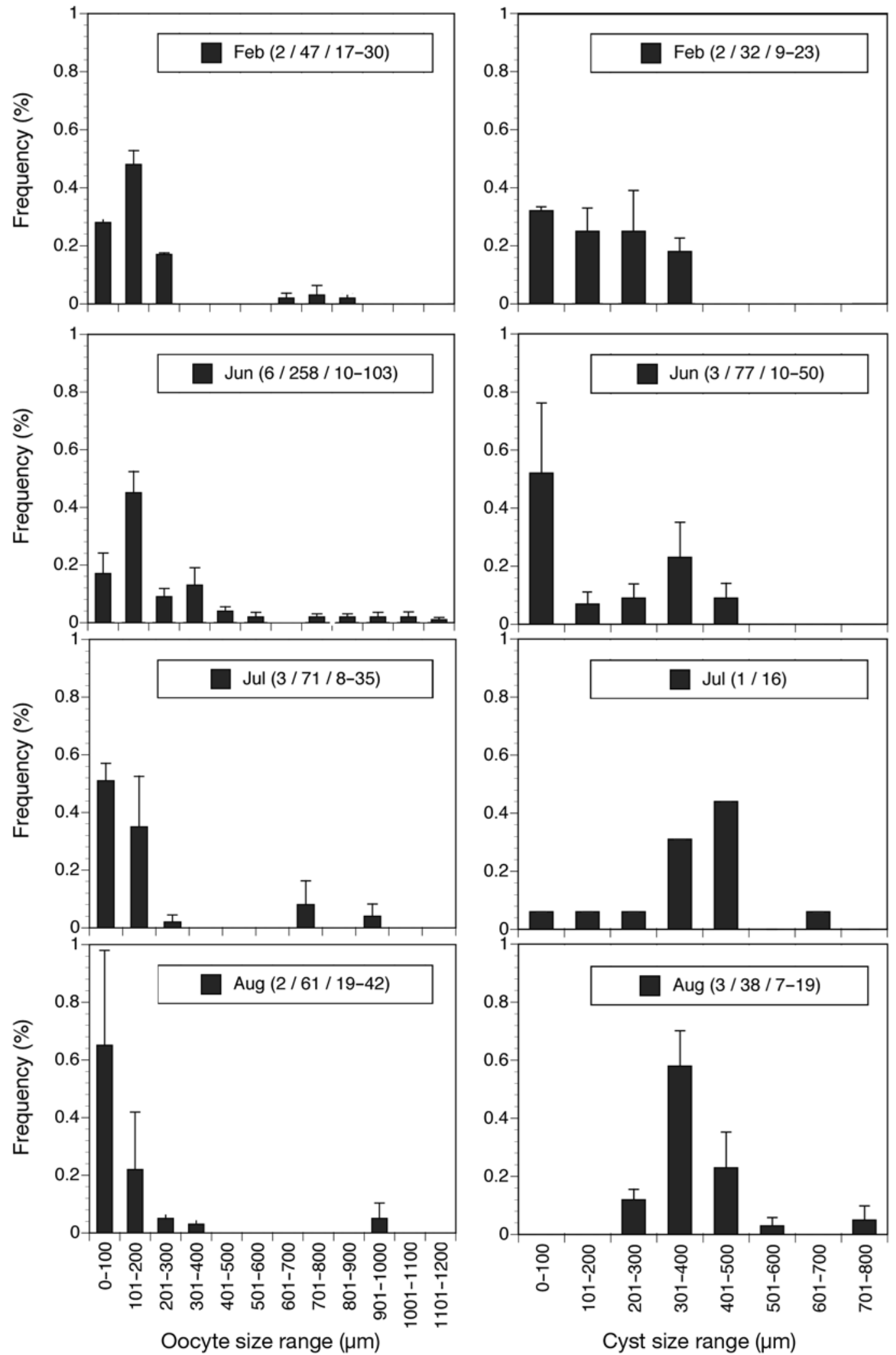

Fig. 5. Anthoptilum murrayi. Relative frequency of oocyte and spermatic cyst size classes in colonies collected in February, June, July and August. Key notation: month (no. colonies/total no. gametes examined/minimum-maximum no. gametes examined in a single colony). Error bars are $+\mathrm{SE}$ 


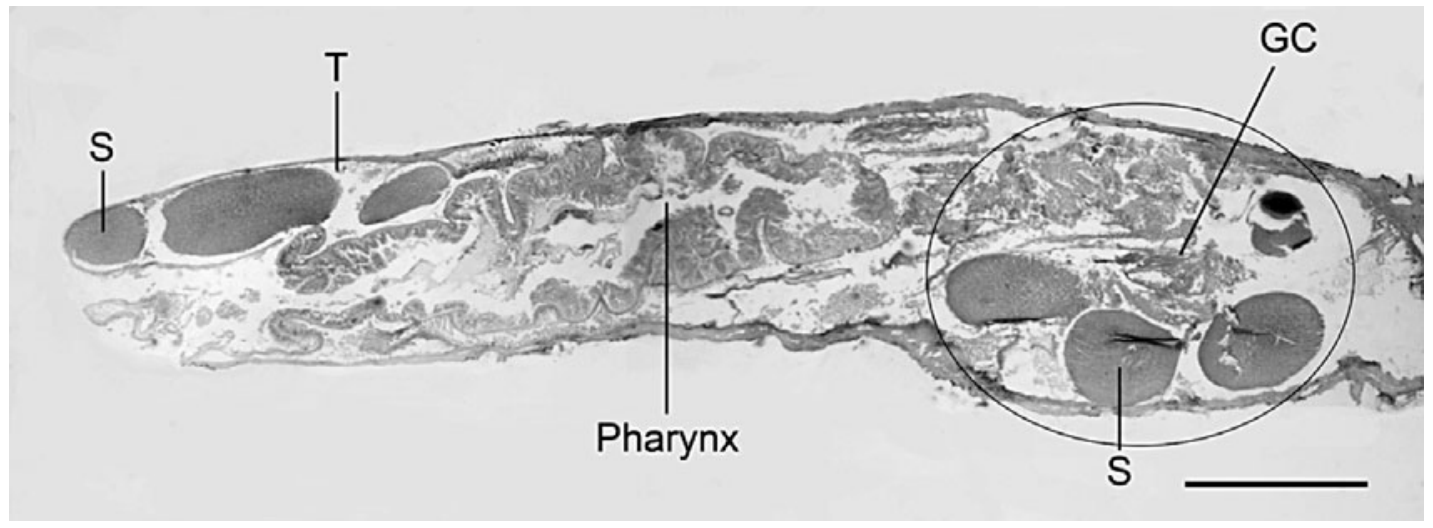

Fig. 6. Anthoptilum murrayi. Longitudinal section of a polyp showing intact Stage III spermatic cysts at the base of autozooids and at the tip of tentacles. S: mature spermatic cysts; T: tentacle; GC: gastric cavity. Scale bar $=600 \mu \mathrm{m}$

Table 1. Sexual pattern and spawning timing of Pennatulacea (data arranged in chronological order of source)

\begin{tabular}{|lccccc|}
\hline Species & Locality & Depth $(\mathrm{m})$ & Sexual pattern & Spawning & Source \\
\hline $\begin{array}{l}\text { Ptilosarcus } \\
\text { guerneyi }\end{array}$ & $\begin{array}{c}\text { Alki Point, Seattle, } \\
\text { USA }\end{array}$ & Shallow & Gonochoric & Late March & Chia \& Crawford (1973) \\
$\begin{array}{c}\text { Kophobelemnon } \\
\text { stelliferum }\end{array}$ & $\begin{array}{c}\text { Porcupine Seabight, } \\
\text { SW Ireland }\end{array}$ & $350-1600$ & Gonochoric & $\begin{array}{c}\text { No signs of seasonal } \\
\text { reproduction }\end{array}$ & Rice et al. (1992) \\
$\begin{array}{c}\text { Umbellula } \\
\text { lindahli }\end{array}$ & $\begin{array}{c}\text { Porcupine Seabight, } \\
\text { SW Ireland }\end{array}$ & $650-3850$ & Gonochoric & Tyler et al. (1995) \\
$\begin{array}{c}\text { Pennatula } \\
\text { aculeata }\end{array}$ & Gulf of Maine, USA & $113-231$ & Gonochoric & Suggests continuous & Eckelbarger et al. (1998) \\
$\begin{array}{c}\text { Renilla } \\
\text { koellikeri }\end{array}$ & Southern California, & Subtidal & Gonochoric & May-July & Tremblay et al. (2004) \\
$\begin{array}{c}\text { Virgularia } \\
\text { juncea }\end{array}$ & Chiton Bay, Taiwan & $0.5-1.0$ & Gonochoric & August/ & Soong (2005) \\
$\begin{array}{c}\text { Pennatula } \\
\text { phosphorea }\end{array}$ & W Scotland & $18.2-19.9$ & Gonochoric & July and/or August & Edwards \& Moore (2008) \\
$\begin{array}{c}\text { Funiculina } \\
\text { quadrangularis }\end{array}$ & W Scotland & $18.9-24.3$ & Gonochoric & October-January & Edwards \& Moore (2009) \\
$\begin{array}{c}\text { Anthoptilum } \\
\text { murrayi }\end{array}$ & SW Atlantic, Brazil & $1300-1799$ & Gonochoric & Continuous & Present study \\
\hline
\end{tabular}

Kophobelemnon stelliferum and Pennatula aculeata (Rice et al. 1992, Eckelbarger et al. 1998; Table 1).

The presence of oocytes in different stages of development in the same polyp can indicate extended and continuous reproductive cycles, and also occurs in other deep-sea octocorals such as Antarctic primnoids (Brito et al. 1997, Orejas et al. 2002, 2007). Brito et al. (1997) identified a similar pattern for Thouarella variabilis, and showed a 2 yr cycle of oogenesis or continuous gametogenesis. Thouarella sp. and Dasystinella acanthina also have a long reproductive cycle with overlapping oocyte generations, each of which lasts more than 1 yr (Orejas et al. 2007). A gametogenic cycle of $18 \mathrm{mo}$, and possibly $2 \mathrm{yr}$, was also observed in Ainigmaptilon antarcticum, and has been seen in other deep-water anthozoans (Orejas et al. 2002). However, a different pattern was seen for 2 other deep-sea primnoid species (Fanyella rossii and F. spinosa) in which reproductive cycles are annual. Cordes et al. (2001) also observed continuous reproduction in the deep-sea brooding alcyonacean Anthomastus ritteri, inferred by the occurrence of gonads in all stages of development in the examined samples, as well as from the random temporal pattern of planulation in the laboratory. While often not possible to obtain, additional monthly samples, or even those from smaller sampling period intervals, would be necessary to produce a more robust estimate of oogenesis duration.

Polyps from different areas of the Anthoptilum murrayi colony bear gametes. In females, most of the oocytes were in the earliest stages of development and polyps from the basal area presented the highest fre- 
quency of very small cells (Fig. 4). The large number of early stage gametes has been reported in other octocorals, including the Pennatulacea (see Edwards \& Moore 2008). According to Brazeau \& Lasker (1989), the persistence of small oocytes throughout the year could indicate that oocytes require more than a single season to mature.

The duration of Stage III oocyte development of Anthoptilum murrayi is unknown as cells of this stage have a wide size range. As such, the presence of large, mature eggs does not necessarily indicate a spawning event is imminent. However, usually cyst development is faster and the spawning event is close when the tails of spermatozoa are present (Brazeau \& Lasker 1989). The final stages of coral spermiogenesis can proceed very rapidly (Harrison \& Wallace 1990). Most (58\%) cysts examined in samples of $A$. murrayi collected in August were Stage III, suggesting that the spawning event was close to this time, compared with $5 \%$ observed in June and none in February. There may be other periods of sperm release during the year, but data in the present study do not show this. A long reproductive cycle, with a probable seasonal spawning period, was also suggested to occur in Dasystinella acanthina and Thouarella sp. (Orejas et al. 2007).

Differences in fecundity among female colonies of Anthoptilum murrayi should be interpreted with caution, as the differences among the polyps suggested it would be necessary to sample more polyps for a more robust analysis. Nevertheless, although fecundity was roughly estimated, the results showed that the mean fecundity of female colonies was high $(31465 \pm 5080$ oocytes per colony). This figure may be an underestimate, since very small oocytes may have been overlooked in the dissected samples. Total fecundity for $A$. murrayi is high and comparable with fecundity estimates in other pennatulacean species, which have ranged from approximately 30000 to 200000 oocytes per colony (Edwards \& Moore 2009). Frequency of large oocytes was low in all examined samples (Fig. 5), suggesting that only a small percentage of oocytes mature at a time. Relatively high total fecundity, but with a small proportion of developing oocytes attaining maximum size at a time, have been recorded in the sea pens Umbellula lindahli and Funiculina quadrangularis (Tyler et al. 1995, Edwards \& Moore 2009).

The absence of embryos or planulae inside the gastric cavities of all examined specimens suggested a broadcast spawning mode of reproduction in Anthoptilum murrayi. To date there are no records of pennatulacean species that are adapted for brooding. It seems that male colonies of $A$. murrayi release intact cysts into the water, since they were seen above the pharynx level of the colonies close to the tentacle tips. Eckelbarger et al. (1998) described a similar occur- rence for Pennatula aculeata and suggested that intact cysts could function as primitive spermatophores, potentially reducing sperm dilution. High fecundity, large egg size (up to $1200 \mu \mathrm{m}$ in histological preparations) that could represent larger targets for sperm (Levitan 1996), primitive spermatophores (sensu Eckelbarger et al. 1998) and large numbers of polyps per colony (up to 655 in examined A. murrayi) are all strategies that could enhance the chance of fertilization (Levitan 1996). There is also evidence of large, aggregated populations of A. murrayi (authors' unpubl. data), as has been observed with other sea pen species (Greathead et al. 2007). This would also increase the chance of fertilization in sessile gonochoric species with a 1:1 sex ratio. All these features may guarantee a successful reproductive strategy in A. murrayi.

Acknowledgements. We thank the Assessment of the Sustainable Yield of the Living Resources in the Exclusive Economic Zone - REVIZEE project and the Campos Basin Deep-Sea Environmental Project/PETROBRAS for donating the specimens for this study. Thanks to PETROBRAS and the United Nations Environment Program (UNEP) for travel grants to D.O.P. and C.B.C. to attend the 4th International Symposium on Deep-Sea Corals. D.O.P. and C.B.C. thank the Conselho Nacional de Desenvolvimento Científico e Tecnológico (CNPq), Brazil, for research fellowships. We gratefully acknowledge MEPS editors and 3 anonymous referees for providing feedback that substantially improved the manuscript. We also thank R. Waller for valuable comments on a revised version of the manuscript and D. Tracey for some text revision.

\section{LITERATURE CITED}

Bayer FM, Grashoff M, Verseveldt J (1983) Illustrated trilingual glossary of morphological and anatomical terms applied to Octocorallia. Brill, Leiden

Benayahu Y (1991) Reproduction and development pathways of Red Sea Xeniidae (Octocorallia, Alcyonacea). Hydrobiologia 216-217:125-130

Benayahu Y (1997) Development episodes in reef soft corals: ecological and cellular determinants. Proc 8th Int Coral Reef Symp 2:1213-1218

Brazeau DA, Lasker HR (1989) The reproductive cycle and spawning in a Caribbean gorgonian. Biol Bull 176:1-7

Brito TAS, Tyler PA, Clarke A (1997) Reproductive biology of the Antarctic octocoral Thouarella variabilis Wright \& Studer, 1889. Proc 6th Int Conf Coelenterate Biology, Nationaal Natuurhistorisch Museum, Leiden, p 63-69

Brooke S, Stone R (2007) Reproduction of deep-water hydrocorals (family Stylasteridae) from the Aleutian Islands, Alaska. Bull Mar Sci 81:519-532

Cairns SD, Gershwin LA, Brook FJ, Pugh P and others (2009) Phylum Cnidaria - corals, medusae, hydroids, myxozoans. In: Gordon DP (ed) New Zealand inventory of biodiversity. Volume 1. Kingdom Animalia: Radiata, Lophotrochozoa, Deuterostomia. Canterbury University Press, Christchurch

Castro CB, Medeiros MS (2001) Brazilian Pennatulacea (Cnidaria: Octocorallia). Bull Biol Soc Wash 10:140-159 
Castro CB, Pires DO, Medeiros MS, Loiola LL, Arantes RCM, Thiago CM, Berman E (2006) Cnidaria: Corais. In: Lavrado HP, Ignácio BL (eds) Biodiversidade bêntica da costa central brasileira. Museu Nacional, Rio de Janeiro, p 147-192

Chia FS, Crawford BJ (1973) Some observations on gametogenesis, larval development and substratum selection of the sea pen Ptilosarcus guerneyi. Mar Biol 23:73-82

Cordes EE, Nybakken JW, VanDykhuizen G (2001) Reproduction and growth of Anthomastus ritteri (Octocorallia: Alcyonacea) from Monterey Bay, California, USA. Mar Biol 138:491-501

> Cryer M, Hartill B, O'Shea S (2002) Modification of marine benthos by trawling: Toward a generalization for the deep ocean? Ecol Appl 12:1824-1839

Deichmann E (1936) The Alcyonaria of the western part of the Atlantic Ocean. Mem Mus Comp Zool Harv 53:1-317

Doulan E (2008) Phylogenetics, systematics and biogeography of deep-sea Pennatulacea (Anthozoa: Octocorallia). Evidence from molecules and morphology. $\mathrm{PhD}$ thesis, University of Southampton

Eckelbarger KJ, Tyler PA, Langton RW (1998) Gonadal morphology and gametogenesis in the sea pen Pennatula aculeata (Anthozoa: Pennatulacea) from the Gulf of Maine. Mar Biol 132:677-690

Edwards DCB, Moore CG (2008) Reproduction in the sea pen Pennatula phosphorea (Anthozoa: Pennatulacea) from the west coast of Scotland. Mar Biol 155:303-314

Edwards DCB, Moore CG (2009) Reproduction in the sea pen Funiculina quadrangularis (Anthozoa: Pennatulacea). Estuar Coast Shelf Sci 82:161-168

Falcão APC, Mauro CA, Cavalcanti GH, Paes JES and others (2006) Biodiversidade marinha brasileira; algumas contribuições da Petrobras. Petrobras, Rio de Janeiro

Greathead CF, Donnan DW, Mair JM, Sounders GR (2007) The sea pens Virgularia mirabilis, Pennatula phosphorea and Funiculina quadrangularis: distribution and conservation issues in Scottish waters. J Mar Biol Assoc UK 87: 1095-1103

Harrison PL, Wallace CC (1990) Reproduction, dispersal and recruitment of scleractinian corals. In: Dubinsky Z (ed) Ecosystems of the World 25. Coral reefs. Elsevier, Amsterdam, p 133-207

Jungersen HFE (1904) Pennatulida. The Danish Ingolf Expedition, Vol 5. Bianco Lunus Bogtrykkeri, Copenhagen, p 1-95

Kahng S, Benayahu Y, Lasker H (2008) A review of sexual reproduction in Octocorallia. Proc 11th Int Coral Reef Symp, 7-11 Jul 2008, Fort Lauderdale, FL, p 98 (Abstract)

Kölliker AV (1880) Report on the Pennatulida dredged by H.M.S. Challenger during the years 1873-76. In: CW Thomson, J Murray (eds) Report of the scientific results of the voyage of H.M.S. Challenger during the years 1873-76. Zoology Vol 1, Part 2, p 1-41

Lavrado HP, Ignácio BL (2006) Biodiversidade bêntica da costa central brasileira. Museu Nacional, Rio de Janeiro

Levitan DR (1996) Effects of gamete traits on fertilization in the sea and the evolution of sexual dimorphism. Nature 382:153-155

McFadden CS, France SC, Sánchez JA, Alderslade P (2006) A molecular phylogenetic analysis of the Octocorallia (Cnidaria: Anthozoa) based on mitochondrial protein-coding sequences. Mol Phylogenet Evol 41:513-527

Molodtsova TN, Sanamyanb NP, Keller NB (2008) Anthozoa from the northern Mid-Atlantic Ridge and Charlie-Gibbs Fracture Zone. Mar Biol Res 4:112-130
Mortensen PB, Buhl-Mortensen L, Gebruk AV, Krylova EM (2008) Occurrence of deep-water corals on the MidAtlantic Ridge based on MAR-ECO data. Deep-Sea Res II 55:142-152

> Orejas C, López-González PJ, Gili JM, Teixidó N, Gutt J, Arntz WE (2002) Distribution and reproductive ecology of the Antarctic octocoral Ainigmaptilon antarcticum in the Weddell Sea. Mar Ecol Prog Ser 231:101-114

> Orejas C, Gili JM, López-González PJ, Hasemann C, Arntz WE (2007) Reproduction patterns of four Antarctic octocorals in the Weddell Sea: an inter-specific, shape, and latitudinal comparison. Mar Biol 150:551-563

Pantin CFA (1948) Notes on microscopical techniques for zoologists. Cambridge University Press, Cambridge

Pinto RP (2008) Novo registro da família Anthoptilidae (Cnidaria: Octocorallia: Pennatulacea) no Atlântico Sul: Anthoptilum murrayi Kölliker 1880. BS dissertation, Universidade Santa Úrsula, Rio de Janeiro

Pires DO, Castro CB, Ratto CC (1999) Reef coral reproduction in the Abrolhos Reef Complex, Brazil: the endemic genus Mussismillia. Mar Biol 135:463-471

Rice AL, Tyler PA, Paterson GJL (1992) The pennatulid Kophobelemnon stelliferum (Cnidaria: Octocorallia) in the Porcupine Seabight (north-east Atlantic Ocean). J Mar Biol Assoc UK 72:417-434

Simpson A (2009) Reproduction in octocorals (Subclass Octocorallia): a review of published literature. Available at www.dmc.maine.edu/sites/watlingsite/PAGES/repro.html

> Soong K (2005) Reproduction and colony integration of the sea pen Virgularia juncea. Mar Biol 146:1103-1109

Thomson JA, Henderson WD (1906) An account of the Alcyonarians collected by the Royal Indian Marine Survey Ship Investigator in the Indian Ocean. Part I. The Alcyonarians of the deep-sea. The Indian Museum, Calcutta, p 1-132

Tremblay ME, Henry J, Anctil M (2004) Spawning and gamete follicle rupture in the cnidarian Renilla koellikeri: effects of putative neurohormones. Gen Comp Endocrinol 137:9-18

Tyler PA, Bronsdon SK, Young CM, Rice AL (1995) Ecology and gametogenic biology of the genus Umbellula (Pennatulacea) in the North Atlantic Ocean. Int Rev Gesamten Hydrobiol 80:187-199

Waller RG (2005) Deep-water Scleractinia (Cnidaria: Anthozoa): current knowledge of reproductive processes. In: Freiwald A, Roberts JM (eds) Cold-water corals and ecosystems. Springer-Verlag, Berlin, p 691-700

Waller RG, Tyler PA, Gage JD (2005) Sexual reproduction in three hermaphroditic deep-sea Caryophyllia species (Anthozoa: Scleractinia) from the NE Atlantic Ocean. Coral Reefs 24:594-602

Waller RG, Tyler PA, Smith CR (2008) Fecundity and embryo development of three Antarctic deep-water scleractinians: Flabellum thouarsii, F. curvatum and F. impensum. DeepSea Res II 55:2527-2534

Williams GC (1995) Living genera of sea pens (Coelenterata: Octocorallia: Pennatulacea): illustrated key and synopses. Zool J Linn Soc 113:93-140

Wourms JP (1987) Oogenesis. In: Giese AC, Pearse JS (eds) Reproduction of marine invertebrates, Vol IX. General aspects: seeking unity in diversity. The Boxwood Press, Palo Alto, CA, p 49-178

Young CM (2003) Reproduction, development and life-history traits. In: Tyler P (ed) Ecosystems of the World 28. Ecosystems of the deep oceans. Elsevier, Amsterdam, p 381-426 